\title{
Importance of Specific Substrate Utilization by Microbes in Microbially Enhanced Coal- Bed Methane Production: A Modelling Study
}

\section{Authors: Simon Emmert, Holger Class, Katherine J. Davis, and Robin Gerlach}

(C) This manuscript version is made available under the CC-BY-NC-ND 4.0 license https:// creativecommons.org/licenses/by-nc-nd/4.0/

Emmert, Simon, Holger Class, Katherine J. Davis, and Robin Gerlach. "Importance of Specific Substrate Utilization by Microbes in Microbially Enhanced Coal-Bed Methane Production: A Modelling Study." International Journal of Coal Geology 229 (September 2020): 103567. doi:10.1016/j.coal.2020.103567. 


\title{
Importance of Specific Substrate Utilization by Microbes in Microbially Enhanced Coal-Bed Methane Production: A Modelling Study
}

\author{
Simon Emmert ${ }^{\mathrm{a}, *}$, Holger Class $^{\mathrm{a}}$, Katherine J. Davis ${ }^{\mathrm{b}}$, Robin Gerlach ${ }^{\mathrm{b}, \mathrm{c}}$ \\ ${ }^{a}$ Dept. of Hydromechanics and Modelling of Hydrosystems, University of Stuttgart, \\ Stuttgart, Germany \\ ${ }^{b}$ Center for Biofilm Engineering, Montana State University, Bozeman, Montana, USA \\ ${ }^{c}$ Dept. of Chemical and Biological Engineering, Montana State University, Bozeman, \\ Montana, USA
}

\begin{abstract}
This study addresses a major gap in the understanding and control of microbially enhanced coal-bed methane (MECBM) production. A mathematical and conceptual model comprises a food-web that includes two types of bacteria and three types of archaea representing substrate-specific members of the community; the microbial community members are potentially interacting by competing for or being inhibited by substrates or products of other microbial community members. The model was calibrated using data sets from two different experimental setups. The calibrated model effectively predicted the methane concentrations within a $7 \%$ range of deviation from the experimental results. The results of additional batch experiments using varied conditions are also reproduced in an attempt to validate the model and to test the hypothesis of amendment-induced stimulation of microbial community members capable of converting coal into substrates available to methane producing microbes. This study significantly enhances the understanding of the complex interactions between microbial activity, substrate-specificity and bio-availability of coal for methane production, and provides the basis for including hydraulic flow and transport processes into future mathematical models important for the design
\end{abstract}

\footnotetext{
* Corresponding author

$U R L$ : simon.emmert@iws.uni-stuttgart.de (Simon Emmert)
}

Preprint submitted to International Journal of Coal Geology

August 9, 2020 
and implementation of more sustainable methods of harvesting methane from un-mineable coalbeds.

Keywords: coal-bed methane, substrate-specific microbes, numerical modelling of microbial processes

\section{Introduction}

Microbially enhanced coal-bed methane (MECBM) production relies on stimulating the native microbial community by providing nutrients essential for increased bioactivity.

Coal beds in the Powder River Basin (PRB), located in Montana and Wyoming, show methane production to be of primarily biogenic origin [1. Methane production in these coal beds seems to be a continuous process, and potentially the production rate as well as the volume of microbially produced methane can be increased through stimulation [2]. It has been demonstrated that stimulating the native microbes with low concentrations of organic amendments can lead to increased methane production [3, 4. Experimental studies focusing on MECBM, performed at Montana State University (MSU) [3, 5, 6], provide the basis for modelling MECBM production with two-phase multi-component transport processes using the numerical simulator $\mathrm{DuMu}^{\mathrm{X}}$ [7]. Numerical modelling has proven to be a valuable tool for testing hypotheses developed from observations and experimental studies and for designing beneficial experiments [8? ], yet only few models describing microbial activity in coal-beds are found in the literature $(9,[10])$.

Coupling flow and transport with microbial activities in a mathematical/ numerical model requires knowledge of the complex and multi-parameterized microbial kinetics. Therefore, this study aims first at validating a substratespecific food web with two types of bacteria where one type solely utilizes coal while the other one is able to utilize both coal and the stimulating amendment. Perspectively, this will allow us to include the coupling to flow and transport on a more solid basis with respect to kinetics. 


\section{Approach}

Multiple experimental studies have been performed regarding the stimulation of coal-to-methane conversion, the microbial community of coal-beds, as well as the effect of different types and concentrations of the added amendment [3, 5, 6. These studies show that amendments are able to stimulate coaldependent methane production [3] and that different microbial communities in coal-beds might have an influence on methane production, while coal treatments for enhancing the coal's bio-availability can also have an effect [11. The latest studies by [5] show that organic amendments increase the biogenic conversion of coal to methane. However, the increase is not proportional to the amendment concentrations [5, 6. Adding small amounts of amendments increases the rate of biogenic methane production while also increasing to some extent the total amount of produced methane. The batch studies performed by [5] provide the basis for the batch calibration of the reaction kinetics in the model.

40 2.1. Experimental study

This model is largely based on a previous study by [5] and we will in brief recapitulate the main aspects of the experimental study here. All experiments were set up in $26 \mathrm{ml}$ Balch tubes and received either $1 \mathrm{~g}$ of ground coal or glass beads and $10 \mathrm{~mL}$ total liquid volume. The inoculum consisted of $1 \mathrm{~mL}$

45 of a previously enriched Flowers-Goodale coal-bed microbial consortium [12]. The amendment, a Chlorella microalga species, was added in form of a $1 \mathrm{~mL}$ suspension resulting in a $0.1 \mathrm{~g} / \mathrm{L}$ amendment concentration in the Balch tubes. The Balch tubes were sealed, mixed regularly and the gas was sampled approx. every 2 weeks.

50 2.2. Modelling study

Hypotheses are derived from experimental evidence [5, 6] and implemented in a newly developed conceptual model of an MECBM food web with two substrate-specific types of bacteria and three types of methane-producing archaea. The basic idea of the conceptual model itself is found in literature 


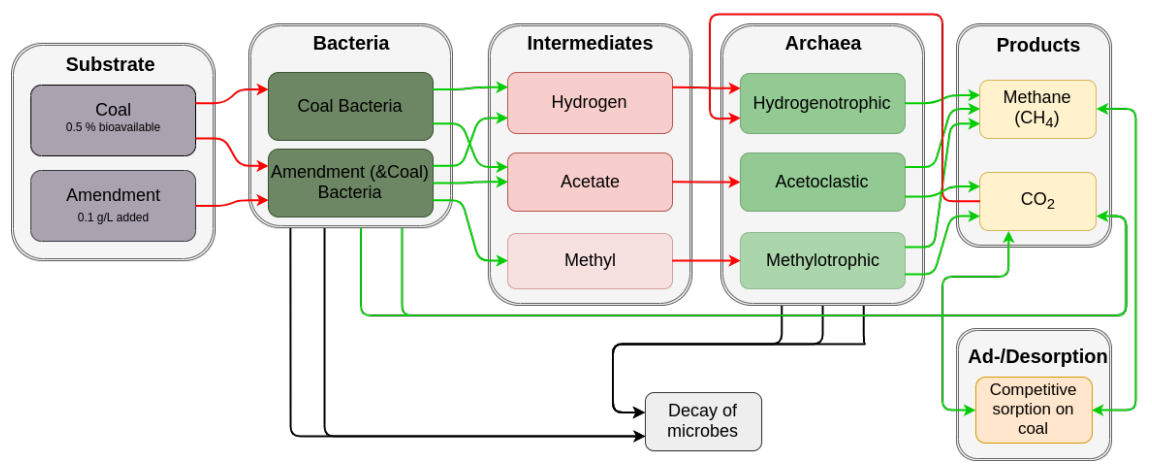

Figure 1: Schematic of the conceptual MECBM food web. The two substrates coal and amendment are considered for the two substrate-specific groups of bacteria which produce biomass, hydrogen, acetate and methyl groups. These intermediates are then assumed to be consumed by methanogenic archaea to produce biomass, methane and $\mathrm{CO}_{2}$.

13, 14, 15, and includes coal as a porous matrix and substrate, the microbial community in form of biomass, amendment as an additional substrate, as well as multiple intermediate products. We consider two fluid phases, where water in the aqueous phase and methane in the gas phase are the main components. The microbial community is divided into two groups. One group consists of two types of microbes converting amendment and/or coal to intermediates. They are assumed to be dominated by and thus labeled "bacteria". The other group consists of three types of archaea using intermediates to produce methane and carbon dioxide (see Figure 1).

Microbial growth rates are implemented using Monod Kinetics, while the decay rates are considered to be first order approximations. Component source and sink terms are calculated using biomass and component-dependent yield reaction terms for each microbial conversion as explained in detail in Section 3.1

We first pursue a calibration of the model using two out of nine available data 70 sets, keeping in mind that the microbial pathways are separated into coal- and amendment-dependent parts. The model is calibrated independently for these two pathways; the resulting combined model provides insight into the discussed 
importance of substrate-specific behavior and amendment-based stimulation of coal-degrading microbes. Beyond calibration, we perform a validation of the developed model concept and demonstrate the importance of substrate-specific microbes and their roles in biogenic methane production.

\section{Model description \& Assumptions / Definition of the System}

The model is implemented in the numerical simulator $\mathrm{DuMu}^{\mathrm{X}}$ and considers two fluid phases (wetting and non-wetting), two immobile phases (coal or glass beads as porous medium and biofilm) as well as up to eight dissolved components. The non-wetting (n) fluid phase consists primarily of $\mathrm{CH}_{4}$ and $\mathrm{CO}_{2}$, the wetting $(\mathrm{w})$ fluid phase consists of brine and contains most of the dissolved components, which namely are amendment (Am) as substrate, the intermediate products acetate $(\mathrm{Ac})$, hydrogen $\left(\mathrm{H}_{2}\right)$ and methyl groups $\left(\mathrm{CH}_{3}\right)$ or the end products, methane $\left(\mathrm{CH}_{4}\right)$ and carbon dioxide $\left(\mathrm{CO}_{2}\right)$ (Figure 2). The system is evaluated on the macro scale, which is represented using averaged quantities for every volume element, the so called representative elementary volume (REV) [16. The model is set up with a cell-centered finite volume scheme and the system of equations is solved fully implicitly for all phases and components, even though some components have a tracer-like behavior, which might be calculated explicitly using previously calculated velocity fields. Details on the equations are presented in Section 4

We assume an ideal gas for the non-wetting phase except for the water and $\mathrm{CO}_{2}$ components, where tabulated values are used [17, 18. $\mathrm{CO}_{2}$ is assumed to be present abundantly, thus carbonate alkalinity and $\mathrm{pH}$ can be assumed to be constant for the sake of simplicity in the model.

In the model, we assume the coal to be homogeneous and without any fractures or other specific features that coal would have in a real coal bed. We consider this justified as the coal from the experimental studies is crushed and sieved to obtain a homogeneous grain size. If the model is applied to a field-size case, the fractures and cleats would have to be embedded using e.g. a discrete 


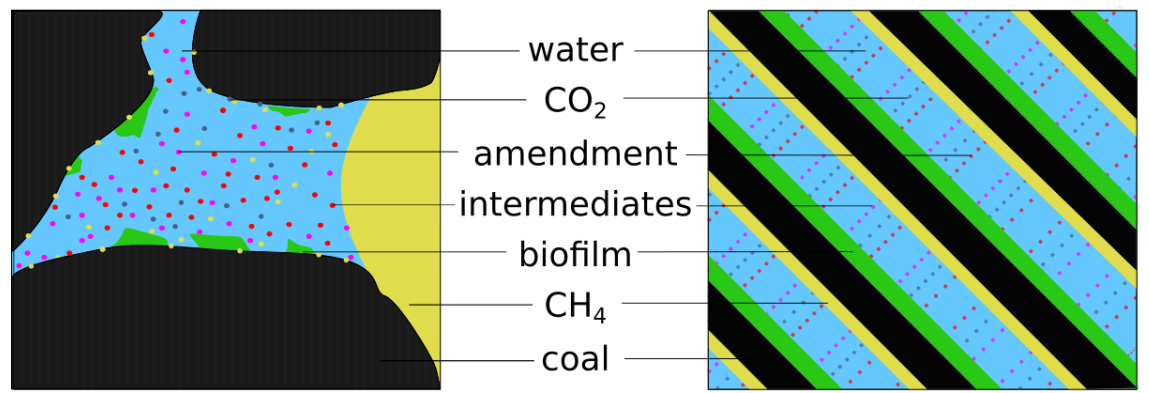

Figure 2: Schematic of the pore to REV scale representation used in the model concept. Scale/Amount not representative.

fracture network as described and available by [19] in the software framework $\mathrm{DuMu}^{\mathrm{X}}$. Adsorption is implemented in the model, yet the study of 20 indicates for the specific laboratory conditions with crushed coal where likely most of the previously adsorbed methane has escaped in this treatment, that lab-specific adsorption parameters would be required to substantiate the model. Since we expect that there is no significant sorption of the newly produced methane under the low-pressure laboratory conditions, we refrained for now from performing extensive experimental studies on sorption under these conditions and recommend it for further investigations beyond the current study.

Regarding the microbial conversion of the coal [3] showed that $99.5 \%$ of the coal energy content remained after the batch experiments. It is estimated from the $\mathrm{CH}_{4}$ production and from coal energy content that $0.5 \%$ of the coal is available for conversion by the microorganisms $[3$. The microorganisms are assumed to consume the easily convertible components of the coal first and the yield coefficients are assumed to be similar to organic compounds with similar oxidation states under anaerobic conditions (see Section 3.1 for more detail).

\subsection{Biogeochemical reactions}

The MECBM microbial community consists of bacteria and archaea. Many experimental studies have been performed in order to characterize the microbial community $21,22,23,24$. This study focuses on the main reactive pathways 
and simplifies the microbial community to groups of bacteria and archaea, which are distinguished by their substrate.

The MECBM process is based on methanogenesis, which is the formation of $\mathrm{CH}_{4}$ through methanogenic archaea. $\mathrm{CH}_{4}$ is the end product of a series of reactions involved in the decomposition of organic matter under anaerobic conditions. The first step is the hydrolysis of complex organic compounds to simpler and more bioavailable organic compounds, such as sugars or amino acids [15].

The second step is fermentation, where complex organic compounds are being fermented to simpler intermediates, such as fatty acids, organic acids, alcohols, as well as the known precursors for methanogenesis acetate, hydrogen and $\mathrm{CO} 2$ [25, 26]. Other bacteria produce acetate, hydrogen and $\mathrm{CO}_{2}$ from these intermediates [26].

The last step is methanogenesis described to be performed by highly specialized archaea using three principally different pathways, namely hydrogen, methyl and acetate reduction [21, 24]. A conceptual overview of all the processes considered here, in form of a flow chart, is given in Figure 1.

\subsubsection{Bacteria}

We operationally define two groups of bacteria depending on their substrate utilization ability. We characterize one group as the "Coal Bacteria" (cb), which we consider to primarily feed on coal and produce acetate and hydrogen from the coal. The other group is the so called "Amendment and Coal Bacteria" (ab), which feed on coal, but are also able to utilize the added substrate "amendment" and produce acetate, hydrogen and methyl groups. While this artificial distinction is not reflecting reality, it allows the model to track growth of microbes based on amendment utilization and coal utilization separately.

\subsubsection{Archaea}

Archaea are separated into three different groups. We consider the acetoclastic archaea (aa) that produce $\mathrm{CH}_{4}$ from acetate using the acetoclastic pathway. 
and $\mathrm{CO}_{2}$ or from acetate to $\mathrm{CH}_{4}$ and bicarbonate $\left(\mathrm{HCO}_{3}^{-}\right)$.

Hydrogenotrophic archaea (ha) represent a group of archaea producing $\mathrm{CH}_{4}$ from hydrogen (as $\mathrm{e}^{-}$donor) and $\mathrm{CO}_{2}$ (as $\mathrm{e}^{-}$acceptor) to $\mathrm{CH}_{4}$ and $\mathrm{H}_{2} \mathrm{O}$.

The methylotrophic archaea (ma) are the group of archaea that produce $\mathrm{CH}_{4}$ from methyl groups, where, in principle, three methyl groups are reduced while one is oxidized to $\mathrm{CO}_{2}$. Even though the methylotrophic pathway is included in the model for the amendment and coal consuming bacteria, the focus is on the acetoclastic and hydrogenotrophic pathways, as they appear to contribute more significantly to $\mathrm{CH}_{4}$ production [27, 28].

\subsubsection{Energetics and bacterial growth}

In this Section, the general energetics and kinetics of substrate utilization and bacterial growth are explained. According to [29], equilibrium calculations are not sufficient to determine concentrations of substances in natural aquatic systems. Therefore, the dynamics of biological, chemical and physical processes must be considered.

For each microbial process, three half-reactions, describing the process of interest, are considered, which generally represent an oxidation, reduction and biomass accumulation reaction, respectively. The half-reaction equations with their respective Gibbs free energy are taken from [29]. One reaction system is explained in the following; all other reaction systems used in the model are given in Appendix A. The half-reactions for a reaction system using coal, in which carbon has an approximate oxidation state of about zero (similar to carbon in glucose or acetate), normalized to the exchange of one e-, and their corresponding Gibbs free energy values $(\Delta G)$ in $k J / m o l$ are:

$$
\begin{gathered}
\Delta \mathrm{G}=-41.924: \quad \frac{1}{24} \mathrm{C}_{6} \mathrm{H}_{12} \mathrm{O}_{6}+\frac{1}{4} \mathrm{H}_{2} \mathrm{O}=\frac{1}{4} \mathrm{CO}_{2}+1 \mathrm{H}^{+}+1 \mathrm{e}^{-} \\
\Delta \mathrm{G}=27.652: \quad \frac{1}{8} \mathrm{CO}_{2}+\frac{1}{8} \mathrm{HCO}_{3}^{-}+1 \mathrm{H}^{+}+1 \mathrm{e}^{-}=\frac{1}{8} \mathrm{CH}_{3} \mathrm{COO}^{-}+\frac{3}{8} \mathrm{H}_{2} \mathrm{O}
\end{gathered}
$$




$$
\Delta \mathrm{G}=100.00: \quad \frac{1}{4} \mathrm{CO}_{2}+\frac{1}{20} \mathrm{NH}_{3}+1 \mathrm{H}^{+}+1 \mathrm{e}^{-}=\frac{1}{20} \mathrm{C}_{5} \mathrm{H}_{7} \mathrm{O}_{2} \mathrm{~N}+\frac{2}{5} \mathrm{H}_{2} \mathrm{O}
$$

These three equations are solved with closing relations. The first one requires the sum of $\mathrm{e}^{-}$has to be 0 . Additionally, the sum of Gibbs free energy has to be 0 for the combined process. Lastly, everything is normalized to one mole of substrate.

The results are component-dependent yields. They are named $Y_{P, S}$ after their substrate $(S)$ and products $(P)$, where $S$ and $P$ are substituted for the respective components. The biomass yields $Y_{X, S}^{P}$ have the microbe $X$ that is growing, the substrate $S$ and, where applicable, the product $P$ they are producing. Solving the resulting system of three linear equations results in a biomass yield as well as a product yield for each reaction. These yields represent the energy balance for the reactions and provide the basis for the biogeochemical reactions.

\section{Mathematical and numerical model}

This Section describes the details of the numerical model. The model consists of component mass balance equations with all flow and transport features. Since the batch system is modelled here as a zero-dimensional process, flow and transport features are not relevant and not described in detail for this study. However we still solve the full system as this model is seen as the first step towards further work and is implemented in a framework that is easily extendable. The full component mass balance equations of this two-phase multi-component system are similar to Eq. 2 in 8 , and the coupling with the reactions is implemented using source terms $q^{\kappa}$ for each component $\kappa$.

The reactive multiphase flow and transport model allows for ad- and desorption of solutes to the coal matrix, however ad- and desorption have very little impact on the output of the numerical model here since ad- and desorption processes as proposed in literature [30, 31 are primarily pressure-driven and pressures were low, i.e. around atmospheric, in the calibration and validation datasets. 
The mass balances for the solid phases, namely for the biologically convertible fraction of coal ("Cc"), two types of bacteria and three types of archaea consist only of a storage and a source term as shown in Eq. 4.

$$
\frac{\partial}{\partial t}\left(\phi_{\varphi} \rho_{\varphi}\right)=q^{\varphi}, \quad \varphi \in\{\mathrm{Cc} ; \mathrm{ab} ; \mathrm{cb} ; \mathrm{aa} ; \mathrm{ha} ; \mathrm{ma}\} .
$$

Here, $\phi_{\varphi}, \rho_{\varphi}$ and $q^{\varphi}$ are the volume fraction, mass density and source term due to biogeochemical reactions of the solid phase $\varphi$. Component source and sink terms are calculated using biomass and component-dependent yield reaction terms for each microbial conversion (see Section 3.1). The porosity and permeability of the system change depending on consumption of coal as well as on growth and decay of biofilm.

\section{Calibration, Validation, and Results}

The calibration uses methane production data from two series of batch experiments [5, 11]; other batch results serve as data for the subsequent validation of the calibrated model. The amendment-dependent parameters are calibrated from a setup with glass beads, formation water and three amendment additions over time (red in Figure 3). Then, the coal-dependent parameters are calibrated independently from another setup with only coal and formation water (black in Figure 3).

Calibrated parameters are the yield coefficients of each microbial species, as well as the growth rates of the microbes. When fitting the parameters, it is important to understand that most parameters listed in Tables B.5. B.6. B.7. B.8 are either pre-calculated using the yield reactions described in Section 3.1 or based on literature values. Some parameters are chosen as being fixed, while others, e.g. the growth rates of the microbes, with a higher uncertainty were included as variables in the calibration. The parameters as well as their theoretical ranges are listed in Tables B.5, B.6, B.7, B.8. The calibration itself is performed with the help of PEST [32].

It is important to note that certain parameters are correlated. This issue is 
addressed by strictly evaluating parameter values, and if a calibration result shows to be at the maximum or minimum range of one parameter, we investigate this behavior separately and reevaluate the model fit again. With this approach we try to achieve a reasonable model fit (as judged by a Mean Absolute Error (MAE), while being aware that the correlations between the parameters might be addressed more thoroughly through improved knowledge regarding the processes involved.

The metrics chosen here to assess the overall match of the simulation results to the experimental data is the Mean Absolute Error. It is the average magnitude of the errors when the absolute differences between the experimental and simulation results are used and have equal weight. The advantage over the commonly used Root Mean Square Error (RMSE) is that the interpretation of the MAE is straightforward, as it describes the average error only and that it allows for varying test sample sizes, whereas the RMSE varies with the variability within the distribution of error magnitudes, with the square root of the number of errors, as well as the magnitude of the average-error (MAE) 33. The calibration itself is performed using both the RMSE and the MAE, as [33, 34] state a combination of both metrics is beneficial to assess model performance. The calibration results are compared to the experimental data in Figure 3 . All other model predictions are compared to the experimental results in Figures 4 5 and 6. ExpGB ${ }^{+++}$marks the experimental results of a glass bead case (GB) with amendment additions on day 0,76 and 117 , while e.g. $\mathrm{DuMu}^{\mathrm{X}} \mathrm{coal}^{---}$ 250 stands for a simulation run that contains coal but does not receive amendments over time $\left({ }^{--}\right)$at any of the three possible addition times. In general, a "+" indicates an amendment addition, whereas a "-" indicates no amendment addition at the three possible addition times. This naming scheme is adapted from [5], where also an overview of amendment additions and samples is given in Figure 1 [5].

The calibration of the model to the experimental data yields an MAE of $0.0852 \mathrm{~mol} / \mathrm{m}^{3}$ for the $\mathrm{GB}^{+++}$case with a maximum methane concentration of $3.84 \mathrm{~mol} / \mathrm{m}^{3}$ (see Figure 44. The $\mathrm{coal}^{---}$case shows a slightly lower MAE 


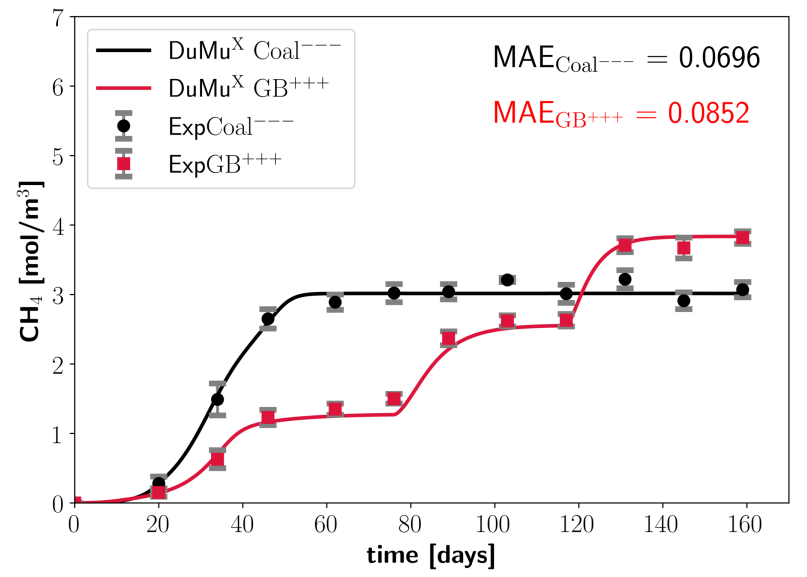

Figure 3: Calibration of simulation model to glass beads and coal scenarios. The plots show methane concentration of the experimental batch systems compared to the simulation results $\left(\mathrm{DuMu}{ }^{\mathrm{X}}\right)$ over time. It shows the two data-sets used for calibration: One system with only coal and no amendment ( $\left.\mathrm{coal}^{--}\right)$added over time and the other set with glass beads and three amendment additions $\left(\mathrm{GB}^{+++}\right)$.

of $0.0696 \mathrm{~mol} / \mathrm{m}^{3}$ with a maximum methane concentration of $3.01 \mathrm{~mol} / \mathrm{m}^{3}$ son to the experimental standard deviations, we consider the calibration of the model successful.

\subsection{Validation}

Figure 4 shows the comparison for the glass beads with different amendment addition strategies. The increase after the amendment additions is captured well, as the experimental data as well as the simulation data coincide. However, 
the simulation appears to underestimate the methane concentration towards the end of the experiments. The MAE is slightly higher at $0.141 \mathrm{~mol} / \mathrm{m}^{3}$ for the $\mathrm{GB}^{++-}$case, and $0.212 \mathrm{~mol} / \mathrm{m}^{3}$ for $\mathrm{GB}^{+--}$, compared with an experimental standard deviation of $0.0868 \mathrm{~mol} / \mathrm{m}^{3}$. Given a total production of only $1.28 \mathrm{~mol} / \mathrm{m}^{3}$ for $\mathrm{GB}^{+--}$, an MAE of $0.212 \mathrm{~mol} / \mathrm{m}^{3}$ is considered large and on the brink of being acceptable (16.58\% relative error), while the standard deviation in the experiments was only $0.078 \mathrm{~mol} / \mathrm{m}^{3}$.

These larger MAEs seem to be the result of an underprediction of methane production in the simulations, which can be attributed to additional methane production in the experiments associated with the inoculum addition. Small amounts of methane (up to $0.68 \mathrm{~mol} / \mathrm{m}^{3}$ ) appear to be generated in $\mathrm{GB}^{---}$ experiments as shown in [5], Figure 2(b).; Davis et al. demonstrate that the inoculum itself potentially adds small amounts of organic compounds in the form of soluble organics or biomass, which can ultimately be converted into methane. For most scenarios, this additional amount of methane is small but in the glass bead only or only one-time amended glass bead systems (e.g. in $\mathrm{GB}^{+--}$) it appears to have a large enough influence to decrease the model fit resulting in fairly large MAEs. Regarding the $\mathrm{GB}^{++-}$case, it is evident that the results match quite well visually. Here, the largest variation is seen in the experimental data between day 125 and the end. Such fluctuations in the experimental data are not captured by the model. The MAE is $0.141 \mathrm{~mol} / \mathrm{m}^{3}$ with a total production of $2.56 \mathrm{~mol} / \mathrm{m}^{3}$, which yields a relative error of $5.51 \%$; again, there is slightly higher methane production observed in the experiments than predicted by the model, possibly due to the discussed introduction (carryover) of organic material with the inoculum as discussed in [5].

Figure 5 shows the coal cases with late amendment additions. The MAE of the initial coal fit is $0.0696 \mathrm{~mol} / \mathrm{m}^{3}$ and remains small at only $0.125 \mathrm{~mol} / \mathrm{m}^{3}$ and $0.161 \mathrm{~mol} / \mathrm{m}^{3}$ respectively for the combined cases of coal and amendment treatments $\left(\mathrm{coal}^{-+-}\right.$and $\left.\mathrm{coal}^{-++}\right)$. Standard deviations of the experimental results are $0.149 \mathrm{~mol} / \mathrm{m}^{3}$ for both cases. Comparing these with the MAE as well as the relative averaged errors over time, the results show very good agreement. 
Coal $^{-+-}$has an error of $2.91 \%$ for a maximum production of $4.29 \mathrm{~mol} / \mathrm{m}^{3}$ and

production. However the overall output of the model is still very close to the experiments. Even with the non-intuitive results after day 136 discussed above, the model still has MAEs in the range of the averaged standard deviations of the experiments with an MAE of $0.315 \mathrm{~mol} / \mathrm{m}^{3}$ compared to an averaged standard 330 $0.427 \mathrm{~mol} / \mathrm{m}^{3}$ for the $\mathrm{coal}^{+++}$case. The maximum observed methane productions are $4.29 \mathrm{~mol} / \mathrm{m}^{3}, 5.57 \mathrm{~mol} / \mathrm{m}^{3}$ and $6.85 \mathrm{~mol} / \mathrm{m}^{3}$ with relative errors of $4.03 \%, 5.65 \%$ and $4.63 \%$ for coal $^{+--}$, coal $^{++-}$and coal ${ }^{+++}$respectively. 


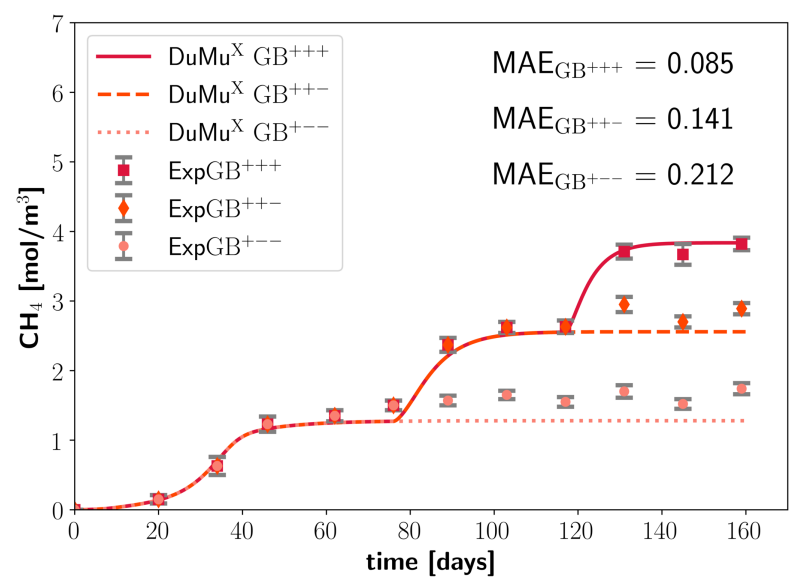

Figure 4: Glass beads plus amendment comparison. The plot compares the calibrated model against the experimental results for a system with glass beads and up to three different amendment additions.

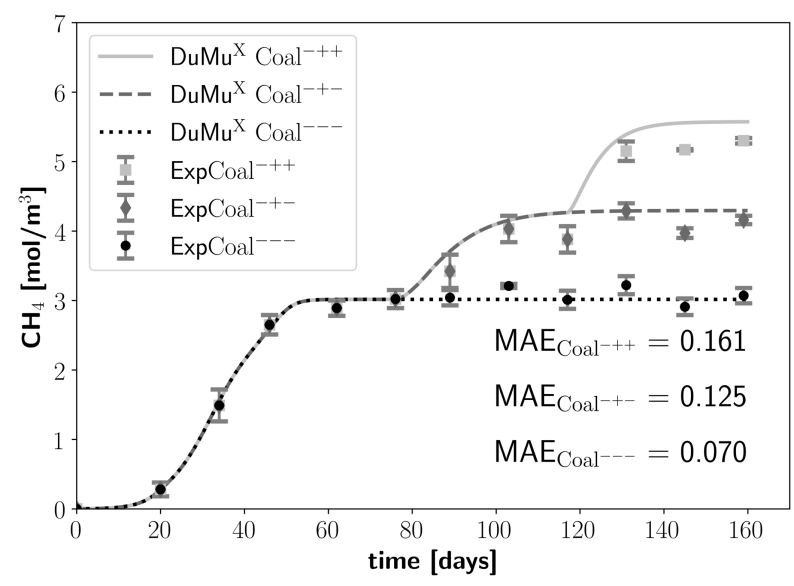

Figure 5: Comparison between model and experiment: initially only coal with amendment additions starting from day 76 . 


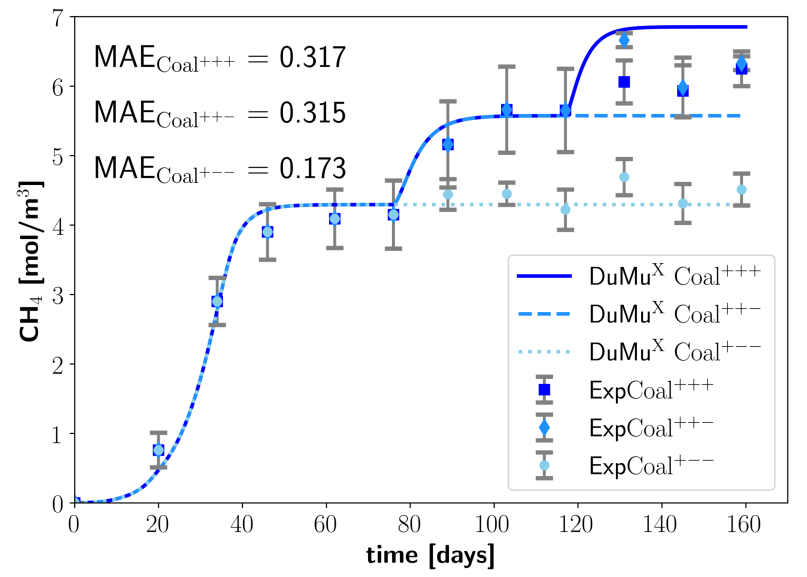

Figure 6: Comparison between model and experiment: coal and amendment additions starting on day 0 .

Comparing the output of the model to the experimental data, the combined setups (Figure 5 and 6) can serve as a validation case for our model. If the assumptions regarding the food web hold true, both the individual and the combined test setups should produce results which are within the range of the experimental error. This behaviour is indeed observed for 8 out of 9 data sets, however a systematic difference is observed for the setups with glass beads and amendment only. While the distinct increases, and therefore the main features are captured, the predicted max. amount of methane produced in all glass bead setups is lower than observed in the experiments (see Figure (4). This behaviour can potentially be attributed to organic carbon available for conversion to methane in the inoculum as shown in [5], Figure 2(b). Therein, Davis et al. suggest: "It is unlikely that all of this carbon was converted to $\mathrm{CH}_{4}$ or IC [inorganic carbon], but it cannot be completely ruled out as a potential carbon source for methane or IC production" [5]. As discussed above the effect of the inoculum as an additional process is not implemented. This was not done 350 here since inoculum was added to all treatments that produced methane and it had not been clear at the time of model conception that methane production 
from the inoculum was going to occur.

Incomplete mixing resulting in diffusion-controlled conversion of organics to methane as a possible reason for this slow continued methane production is unlikely as the Balch tubes were shaken regularly. With at least parts of the continued methane production being clearly attributed to the inoculum [5], implementation of diffusion-limited processes into the model was not pursued here since it would have introduced additional complexity into the model, which was not experimentally justified.

The setups initially with coal only and amendment additions after day 76 (Figure 5) show very good agreement, with MAEs almost identical to the calibrated glass-beads fit. The second and third increases due to amendment additions level out at the experimentally observed methane concentrations; however they the maximum methane concentration is reached slightly earlier in the simulation compared to the experiments. This is not too surprising since the processes are calibrated separately and are independent from each other as long as enough substrate is available. The effect where different microbes might compete for the same substrate is only observed when most of the amendment or coal is already consumed, which in our cases is only the case towards the end of the experiments.

The combined setups with coal and amendment additions starting at the beginning of the experiments (Figure 6) show visible differences in the plot which are confirmed by greater MAE values. While the MAE of coal ${ }^{+--}$is in the range of the previous MAEs of other predicitions, MAEs for $\mathrm{coal}^{+++}$and coal ${ }^{++-}$ 375 show to be the largest over the entire data set. This can be attributed partially to the mismatches of the initial increase in methane production during the first 60 days, but especially the large MAEs of coal $^{+++}$and coal ${ }^{++-}$are due to the values after day 120. A faster increase in methane production is especially visible for the second and third amendment addition, which is consistent with the results from Figure 5 .

For the other two setups, the experimental standard deviations are already greater and the values of the two different experimental setups almost coin- 
cide. These experimental results are discussed in detail in [5] and the possible reasons can not be addressed by a mathematical model of the type used here. However, the simulation shows the expected behaviour of a third (coal ${ }^{+++}$), yet slightly smaller increase than the first and second increase or no increase for no additional amendment addition respectively ( $\mathrm{coal}^{++-}$and $\mathrm{coal}^{+--}$).

With these results the model reflects well the behavior of the experimental systems and indicates that the general assumptions, the reaction kinetics, and the included microbiological pathways can be considered successfully validated. This strongly supports the hypothesis of a coal and amendment utilizing part of the microbial community being stimulated by the amendment additions, which results in an increase in biomass and an accelerated conversion of the bioavailable fraction of coal to products available to methanogenic archaea. As mentioned above, further work related to the possible effect of adsorption for this experimental setup is recommended. In general, the results show that the numerical model is capable of capturing the relevant processes for MECBM production.

\section{Discussion}

As mentioned above, the hypothesis of substrate-specific microbes involved in MECBM production is strongly supported by this calibration and validation study. The parameters for the two different processes were calibrated independently, and with the calibrated parameters the model is able to reproduce the combined results. In the absence of tools allowing for monitoring of carbon flux from coal and amendment separately through these coal converting consortia, a quantitative assessment and evaluation of substrate-specific activities can only be achieved with mathematical/numerical tools.

The model assumes that $0.5 \%$ of the coal is available for the microbes to be converted. This assumption is taken from [3] and was based on the coal energy content before and after batch studies. Changing the fraction of bioavailable coal to a value other than $0.5 \%$ would have no basis in the literature and leads to an 
overestimation of the methane production or when attempting to refit the model with these values, exceeds the physically plausible ranges of the parameters in many cases.

Moreover, the question of the correct or representative coal-composition remains. As mentioned in Section 3.1, the oxidation state of the coal from the $\mathrm{PRB}$ is calculated to be around -1 when taking the coal values from the latest studies in 35. Yet, when calculating the parameter's ranges, we use Gibbsfree-energy calculations based on glucose. The microbes only convert a small easily bioavailable fraction of the coal, while other parts of the coal are not converted. When assuming this, the difference between the amendment and the coal is relevant. The amendment in the experiments consists of algae [5], which are also assumed to behave like glucose for the Gibbs-free-energy calculations. Hence, the yields of biomass relative to coal and amendment are equal, but the total amount and availability of the amendment is assumed to be higher, as the structure and composition of the amendment is already similar to microbial biomass. However, the two different substrates coal and amendment are similar according to the thermodynamic reaction kinetics, yet different in the way the microbes are able to access and utilize them.

Minor mismatches between simulations and experimental batch results show room for improvement regarding the conceptual model or the experiments including a need for uncertainty assessment as well as for a sensitivity analyses of all parameters used in the model. Especially for the glass bead cases, continuous methane production is observed in the experiment, but not in the model. Even though this increases the MAE, we want to reiterate that the overall fit is considered good with the model predictions remaining in the range of the standard deviation of the experimental results. Acknowledging that experimental results, even if they show a low standard deviation, still have underlying uncertainty gives us further confidence in the model, as this uncertainty puts the modelling results in the same range of deviation as the experimental results. Further studies could focus on quantifying this uncertainty with the aim of understanding the processes involved. However, adding more complexity to a model, without 
further detailed knowledge of the processes involved would not improve our current understanding of MECBM production. This heavily parameterized model is able to produce plausible results because literature values and Gibbs free energy calculations according to [29] provide narrow ranges for each parameter. Without these ranges based on a-priori knowledge, many parameters would be heavily correlated and the best fit could potentially result in parameters that are out of their physically meaningful range. This shows that for a system like the MECBM model, the set-up, and parameter values, have to be chosen based on independent experimentation and well-founded calculations. Additionally, a step-wise calibration and setup of the model, as proposed here, is advised.

The implementation of the model within the software framework $\mathrm{DuMu}^{\mathrm{X}}[7]$ allows for modeling flow, transport, and reactions. $\mathrm{DuMu}^{\mathrm{X}}$ is able to solve flow, transport and bio-geochemical reactions fully implicitly. Flow and transport capabilities were not tested in this study, only the reactions were calibrated and validated. Therefore, beyond the present study it is required to include this validation of the conceptual approach and the kinetics of the reactions in well-controlled flow experiments, such as the column experiments of 35.

\section{Conclusions}

MECBM production on the field scale involves strong interactions of microbial activity with flow and transport processes, thus featuring additional complexity introduced by the bio-geochemical processes. This study demonstrates the need for a solid understanding of the basic metabolic pathways as they were implemented qualitatively in a proposed food web and investigated quantitatively using a systematic comparison with experimental results.

The hypothesis of amendment-stimulated growth of coal-degrading microbes is strongly supported by this study. The model was calibrated using conceptually substrate specific microbes, and the simulation results match the experimental data well. This study lays a foundation for understanding the interaction be- 
tween microbes, nutrients, and the coal matrix. The coal bio-availability was estimated for this study according to experimental data and proves to be sufficient for the numerical model. Many detailed calculations and experimental investigations were necessary to set up a numerical model capable of modelling this. Including complex "machines" like microbes into mathematical models involves a large number of parameters with influence on their behaviour, which are hard or impossible to accurately estimate in their entirety [36, 37].

The model will be extended in the future to continuous flow studies, which involves additional interactions with flow and transport. Reactive transport can be modelled and the model can be used to test hypotheses not easily tested using experiments. This involves the basic assumptions of the coal's bio-availability, the amendment transport and possibly retardation. Additionally, the biofilm conditions and distribution can change due to flow and transport. Biofilm detachment and attachment might play a role and can be investigated using the model. This mathematical and conceptual model shows the importance of specific substrate utilization by microbes in the subsurface and provides a tool for further investigations in the field of MECBM production.

\section{Data Availability}

Datasets related to this article can be found at https://doi.org/10.18419/ darus-636, hosted at DaRUS (Emmert, Simon; Class, Holger; Davis, Katherine; Gerlach, Robin, 2020, "Generated Model Output Data", https://doi. org/10.18419/darus-636, DaRUS, DRAFT VERSION).

Access to the code is possible viahttps://git.iws.uni-stuttgart.de/dumux-pub/

emmert2020a.git

\section{References}

[1] R. M. Flores, C. A. Rice, G. D. Stricker, A. Warden, M. S. Ellis, घ Methanogenic pathways of coal-bed gas in the Powder River Basin, United States: The geologic factor, International Journal of Coal Geology 76 (1) 
(2008) 52-75, microbes, Methanogenesis, and Microbial Gas in Coal. doi:10.1016/j.coal.2008.02.005

[2] E. Meredith, J. Wheaton, S. Kuzara, Coalbed-methane Basics: Ten Years of Lessons from the Powder River Basin, Montana, MBMG, 2012.

[3] E. P. Barnhart, K. J. Davis, M. Varonka, W. Orem, A. B. Cunningham, B. D. Ramsay, M. W. Fields, Enhanced coal-dependent methanogenesis coupled with algal biofuels: Potential water recycle and carbon capture, International Journal of Coal Geology 171 (2017) 69-75.

[4] Z. Bi, J. Zhang, S. Park, S. Harpalani, Y. Liang, A formation water-based nutrient recipe for potentially increasing methane release from coal in situ, Fuel 209 (2017) 498-508.

[ [5] K. J. Davis, E. P. Barnhart, M. W. Fields, R. Gerlach, Biogenic coal-tomethane conversion efficiency decreases after repeated organic amendment

515 _ Energy \& Fuels 32 (3) (2018) 2916-2925. doi:10.1021/acs.energyfuels. $7 \mathrm{~b} 03426$.

URL https://doi .org/10.1021/acs .energyfuels .7b03426

[6] K. J. Davis, S. Lu, E. P. Barnhart, A. E. Parker, M. W. Fields, R. Gerlach, Type and amount of organic amendments affect enhanced biogenic methane production from coal and microbial community structure, Fuel 211 (2018) 600-608. doi:10.1016/j.fuel.2017.09.074.

口 URL http://www.sciencedirect.com/science/article/pii/ S0016236117311833

[7] T. Koch, D. Gläser, K. Weishaupt, S. Ackermann, M. Beck, B. Becker, 525 S. Burbulla, H. Class, E. Coltman, S. Emmert, et al., Dumu ${ }^{x} 3$-an opensource simulator for solving flow and transport problems in porous media with a focus on model coupling, arXiv preprint arXiv:1909.05052. 
[8] J. Hommel, E. Lauchnor, A. Phillips, R. Gerlach, A. B. Cunningham, R. Helmig, A. Ebigbo, H. Class, A Revised Model for Microbially Induced Calcite Precipitation: Improvements and new Insights Based on Recent Experiments, Water Resources Research 51 (5) (2015) 3695-3715.

[9] A. Sharma, A. Jagarapu, C. Micale, D. Walia, S. Jackson, P. S. Dhurjati, Modeling framework for biogenic methane formation from coal, Energy \& Fuels 32 (8) (2018) 8453-8461. arXiv:https://doi.org/10.1021/acs. energyfuels.8b01298, doi:10.1021/acs.energyfuels.8b01298 URL https : //doi .org/10.1021/acs .energyfuels.8b01298

[10] G. Senthamaraikkannan, I. Gates, V. Prasad, Development of a multi1. scale microbial kinetics coupled gas transport model for the simulation of biogenic coalbed methane production, Fuel 167 (2016) 188 - 198. doi:https://doi.org/10.1016/j.fuel.2015.11.038. URL http://www.sciencedirect.com/science/article/pii/ S0016236115011886

[11] K. J. Davis, R. Gerlach, Transition of biogenic coal-to-methane conversion

a from the laboratory to the field: A review of important parameters 545 and studies, International Journal of Coal Geology 185 (2018) 33-43. doi:10.1016/j.coal.2017.11.006

a URL http://www.sciencedirect.com/science/article/pii/ S0166516217306523

[12] E. P. Barnhart, E. P. Weeks, E. J. Jones, D. J. Ritter, J. C. McIntosh, A. C. Clark, L. F. Ruppert, A. B. Cunningham, D. S. Vinson, W. Orem, et al., Hydrogeochemistry and coal-associated bacterial populations from a methanogenic coal bed, International Journal of Coal Geology 162 (2016) $14-26$.

[13] S. Zinder, Microbiology of anaerobic conversion of organic wastes to 555 methane: recent developments, Am. Soc. Microbiol. News;(United States) 50 (7). 
[14] S. H. Zinder, Physiological ecology of methanogens, in: Methanogenesis, Springer, 1993, pp. 128-206.

[15] S. Y. Park, Y. Liang, Biogenic methane production from coal: a review on recent research and development on microbially enhanced coalbed methane (mecbm), Fuel 166 (2016) 258-267.

[16] J. Bear, Dynamics of fluids in porous media, Courier Corporation, 2013.

[17] W. Wagner, J. R. Cooper, A. Dittmann, J. Kijima, H.-J. Kretzschmar, A. Kruse, R. Mares, K. Oguchi, H. Sato, I. Stocker, O. Sifner, Y. Takaishi, I. Tanishita, J. Trubenbach, T. Willkommen, The IAPWS Industrial a Formulation 1997 for the Thermodynamic Properties of Water and Steam Journal of Engineering for Gas Turbines and Power 122 (1)

1. (2000) 150-184. arXiv:https://asmedigitalcollection.asme.org/ gasturbinespower/article-pdf/122/1/150/5548474/150\_1.pdf,

570 doi:10.1115/1.483186.

URL https : //doi .org/10.1115/1.483186

[18] R. Span, W. Wagner, A new equation of state for carbon dioxide covering the fluid region from the triple-point temperature to $1100 \mathrm{k}$ at pressures up to $800 \mathrm{mpa}$, Journal of physical and chemical reference data 25 (6) (1996) $1509-1596$.

[19] D. Gläser, B. Flemisch, R. Helmig, H. Class, A hybrid-dimensional discrete fracture model for non-isothermal two-phase flow in fractured porous media, GEM - International Journal on Geomathematics 10 (1) (2019) 5. doi:10.1007/s13137-019-0116-8. URL https://doi.org/10.1007/s13137-019-0116-8

[20] S. Scholz, K. J. Davis, R. Gerlach, A. B. Cunningham, J. Hommel, H. Class, R. Helmig, Modelling microbially enhanced coal-bed methane production: From batch experiments to a numerical model, in: Proceedings of Computational Methods in Water Resources XXII, 2018, pp. 1-2. 
[25] P. Gupta, A. Gupta, Biogas production from coal via anaer605

[26] B. Schink, Energetics of Syntrophic Cooperation in Methanogenic Degrada610

[27] D. White, et al., Physiology and biochemistry of prokaryotes, Oxford University Press, 2000. 
[28] J.-L. Garcia, B. Ollivier, W. B. Whitman, The order methanomicrobiales, The prokaryotes: Volume 3: Archaea. Bacteria: Firmicutes, actinomycetes (2006) 208-230.

[29] P. McCarty, Energetics of organic matter degradation, Water pollution microbiology (1972) 91-108.

[30] F. Medina, M. Peszynska, Hybrid modeling and analysis of multicomponent adsorption with applications to coalbed methane, NOVA SCIENCE PUBLISHERS, 2016, Ch. 1, pp. 1-52.

[31] D. D. Do, et al., Adsorption analysis: equilibria and kinetics, Vol. 2, Imperial college press London, 1998.

[32] J. Doherty, Calibration and uncertainty analysis for complex environmental models, Watermark Numerical Computing, 2015.

[33] C. J. Willmott, K. Matsuura, Advantages of the Mean Absolute Error (MAE) over the Root Mean Square Error (RMSE) in Assessing Average Model Performance, Climate Research 30 (2005) 79. doi:10.3354/ cr030079.

[34] T. Chai, R. R. Draxler, Root mean square error (rmse) or mean absolute error (mae)? arguments against avoiding rmse in the literature

1. Geoscientific Model Development 7 (3) (2014) 1247-1250. doi:10.5194/ gmd-7-1247-2014.

URL https://www.geosci-model-dev.net/7/1247/2014/

[35] K. Davis, G. Platt, E. Barnhart, R. Hiebert, R. Hyatt, M. Fields, R. Ger635 lach, Biogenic coal-to-methane conversion can be enhanced with small additions of algal amendment in field-relevant upflow column reactors, Fuel 256. doi:10.1016/j.fuel.2019.115905.

[36] T. Scheibe, S. Yabusaki, Scaling of flow and transport behavior in heterogeneous groundwater systems, Advances in Water Resources 22 (3) (1998) 
[37] J. Zhao, T. D. Scheibe, R. Mahadevan, Model-based analysis of the

a role of biological, hydrological and geochemical factors affecting uranium

bit.23096, doi:10.1002/bit.23096

URL https://onlinelibrary.wiley.com/doi/abs/10.1002/bit.23096

[38] D. B. Archer, G. E. Powell, Dependence of the Specific Growth Rate of

[39] X. Pan, I. Angelidaki, M. Alvarado-Morales, H. Liu, Y. Liu, X. Huang,

$$
\begin{aligned}
& 796 \text { - 806. doi:https://doi.org/10.1016/j.biortech.2016.07.032 } \\
& \text { URL http://www.sciencedirect.com/science/article/pii/ }
\end{aligned}
$$

[40] P. V. Welander, Analysis of Methylotrophic Methanogenesis in Methanosarcina Barkeri Fusaro, ProQuest, 2007.

[41] J. A. Robinson, J. M. Tiedje, Competition Between Sulfate-Reducing and Methanogenic Bacteria for $\mathrm{H} 2$ under Resting and Growing Conditions, Archives of Microbiology 137 (1) (1984) 26-32.

[42] A. H. Sørensen, B. K. Ahring, Measurements of the Specific Methanogenic Activity of Anaerobic Digestor Biomass, Applied Microbiology and Biotechnology 40 (2) (1993) 427-431.

[43] G. Zhang, N. Jiang, X. Liu, X. Dong, Methanogenesis from Methanol at Low Temperatures by a Novel Psychrophilic Methanogen, "Methanolobus 
psychrophilus" sp. nov., prevalent in Zoige Wetland of the Tibetan Plateau, Applied and Environmental Microbiology 74 (19) (2008) 6114-6120. 
Appendix A. Energetics and bacterial growth

Table A.1: Energetics and reactions system for bacteria using glucose.

$\Delta G$ in Equation

$k J / m o l$

$-41.924$

$\frac{1}{24} \mathrm{C}_{6} \mathrm{H}_{12} \mathrm{O}_{6}+\frac{1}{4} \mathrm{H}_{2} \mathrm{O}=\frac{1}{4} \mathrm{CO}_{2}+1 \mathrm{H}^{+}+1 \mathrm{e}^{-}$

(A.1) Eq. 29 in 29]

$100.00 \quad \frac{1}{4} \mathrm{CO}_{2}+\frac{1}{20} \mathrm{NH}_{3}+1 \mathrm{H}^{+}+1 \mathrm{e}^{-}=\frac{1}{20} \mathrm{C}_{5} \mathrm{H}_{7} \mathrm{O}_{2} \mathrm{~N}+\frac{2}{5} \mathrm{H}_{2} \mathrm{O}$

Eq. 32 in 29 ]

$27.652 \frac{1}{8} \mathrm{CO}_{2}+\frac{1}{8} \mathrm{HCO}_{3}^{-}+1 \mathrm{H}^{+}+1 \mathrm{e}^{-}=\frac{1}{8} \mathrm{CH}_{3} \mathrm{COO}^{-}+\frac{3}{8} \mathrm{H}_{2} \mathrm{O}$

Eq. 14 in 29$]$

40.459

$$
1 \mathrm{H}^{+}+1 \mathrm{e}^{-}=\frac{1}{2} \mathrm{H}_{2}
$$

(A.4) Eq. 28 in 29]

37.510

$$
\frac{1}{6} \mathrm{CO}_{2}+1 \mathrm{H}^{+}+1 \mathrm{e}^{-}=\frac{1}{6} \mathrm{CH}_{3} \mathrm{COH}+\frac{1}{6} \mathrm{H}_{2} \mathrm{O}
$$

(A.5) Eq. 26 in 29 
Table A.2: Energetics and reactions system for archaea using intermediates.

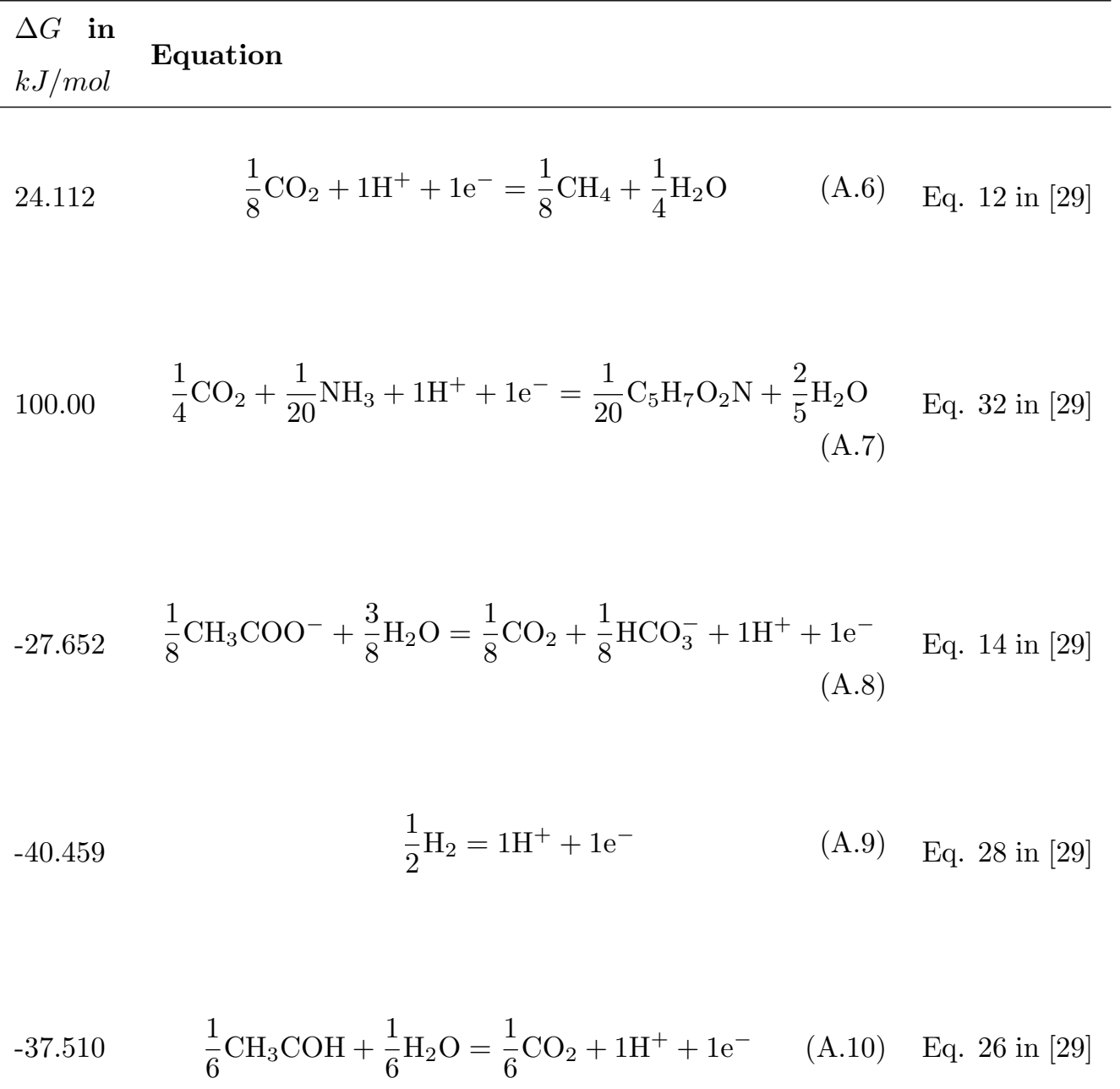




\section{Appendix B. Parameter ranges, initial conditions and sources}

Table B.3: Initial biomass conditions and densities.

\begin{tabular}{|c|c|c|c|}
\hline Parameter & Value & Source & Brief Description \\
\hline$\phi_{\mathrm{cb}, 0}$ & $1 * 10^{-5}[-]$ & Estimated & $\begin{array}{l}\text { Initial volume fraction of coal } \\
\text { consuming bacteria }\end{array}$ \\
\hline$\phi_{\mathrm{ab}, 0}$ & $1 * 10^{-5}[-]$ & Estimated & $\begin{array}{l}\text { Initial volume fraction of amend- } \\
\text { ment and coal consuming bacte- } \\
\text { ria }\end{array}$ \\
\hline$\phi_{\text {ha }, 0}$ & $1 * 10^{-6}[-]$ & $\begin{array}{l}\text { Estimated, approx. one } \\
\text { order of magnitude } \\
\text { lower than bacteria }\end{array}$ & $\begin{array}{l}\text { Initial volume fraction of hy- } \\
\text { drogenotrophic archaea }\end{array}$ \\
\hline$\phi_{\mathrm{aa}, 0}$ & $1 * 10^{-6}[-]$ & $\begin{array}{l}\text { Estimated, approx. one } \\
\text { order of magnitude } \\
\text { lower than bacteria }\end{array}$ & $\begin{array}{l}\text { Initial volume fraction of aceto- } \\
\text { clastic archaea }\end{array}$ \\
\hline$\phi_{\mathrm{ma}, 0}$ & $1 * 10^{-6}[-]$ & $\begin{array}{l}\text { Estimated, approx. one } \\
\text { order of magnitude } \\
\text { lower than bacteria }\end{array}$ & $\begin{array}{l}\text { Initial volume fraction of methy- } \\
\text { lotrophic archaea }\end{array}$ \\
\hline$\phi_{\mathrm{Cc}, 0}$ & $\begin{array}{l}2.53 \\
10^{-2}[-]\end{array}$ & $\begin{array}{l}\text { Derived from experi- } \\
\text { mental concentration }\end{array}$ & $\begin{array}{l}\text { Initial volume fraction of coal, } \\
\text { corresponding to } 100 \mathrm{~g} / \mathrm{L}\end{array}$ \\
\hline$\rho_{\mathrm{Cc}}$ & $1250 \frac{\mathrm{kg}}{\mathrm{m}^{3}}$ & $\begin{array}{l}\text { Average measurement } \\
\text { value } 35\end{array}$ & Density of coal \\
\hline$\rho_{i}$ & $10 \frac{\mathrm{kg}}{\mathrm{m}^{3}}$ & Estimated, see 8 & Dry density of all microbes \\
\hline
\end{tabular}


Table B.4: Initial component concentrations

\begin{tabular}{lrll}
\hline \multicolumn{1}{l}{ Parameter } & Value & Source & Brief Description \\
\hline$C_{\mathrm{Am}, 0}$ & $0.1 \mathrm{~g} / \mathrm{L}$ & Experimental value [5] & Initial concentration of amendment \\
$C_{\mathrm{H}_{2}, 0}$ & $0.0 \mathrm{~g} / \mathrm{L}$ & Experimental value [5] & Initial concentration of hydrogen \\
$C_{\mathrm{Ac}, 0}$ & $0.0 \mathrm{~g} / \mathrm{L}$ & Experimental value [5] & Initial concentration of acetate \\
$C_{\mathrm{CH}_{3}, 0}$ & $0.0 \mathrm{~g} / \mathrm{L}$ & Experimental value [5] & Initial concentration of methyl \\
\hline
\end{tabular}

Table B.5: Microbial growth rates: The rates are named $\mu_{X, S}^{\mathrm{P}}$ after the microbe $X$ they are growing, their substrate $(S)$ and where applicable the product $P$ that is forming corresponding to the respective growth.

\begin{tabular}{|c|c|c|c|}
\hline Parameter & Value & Source & Brief Description \\
\hline$\mu_{\mathrm{cb}, \mathrm{Cc}}^{\mathrm{Ac}}$ & $0.308 \mathrm{~d}^{-1}$ & $\begin{array}{l}\text { Estimated range: } \\
0.05-0.5 \mathrm{~d}^{-1}\end{array}$ & $\begin{array}{l}\text { Maximum specific growth rate constant } \\
\text { of coal consuming bacteria on coal pro- } \\
\text { ducing Acetate }\end{array}$ \\
\hline$\mu_{\mathrm{cb}, \mathrm{Cc}}^{\mathrm{H}_{2}}$ & $0.308 \mathrm{~d}^{-1}$ & $\begin{array}{l}\text { Estimated range: } \\
0.05-0.5 \mathrm{~d}^{-1}\end{array}$ & $\begin{array}{l}\text { Maximum specific growth rate constant } \\
\text { of coal consuming bacteria on coal pro- } \\
\text { ducing hydrogen }\end{array}$ \\
\hline$\mu_{\mathrm{ab}, \mathrm{Cc}}^{\mathrm{Ac}}$ & $0.054 \mathrm{~d}^{-1}$ & $\begin{array}{l}\text { Estimated range: } \\
0.05-0.5 \mathrm{~d}^{-1}\end{array}$ & $\begin{array}{l}\text { Maximum specific growth rate constant of } \\
\text { amendment and coal consuming bacteria } \\
\text { on coal producing Acetate }\end{array}$ \\
\hline$\mu_{\mathrm{ab}, \mathrm{Cc}}^{\mathrm{H}_{2}}$ & $0.054 \mathrm{~d}^{-1}$ & $\begin{array}{l}\text { Estimated range: } \\
0.05-0.5 \mathrm{~d}^{-1}\end{array}$ & $\begin{array}{l}\text { Maximum specific growth rate constant of } \\
\text { amendment and coal consuming bacteria } \\
\text { on coal producing hydrogen }\end{array}$ \\
\hline$\mu_{\mathrm{ab}, \mathrm{Am}}^{\mathrm{Ac}}$ & $0.771 \mathrm{~d}^{-1}$ & $\begin{array}{l}\text { Estimated range: } \\
0.1-1.5 \mathrm{~d}^{-1}\end{array}$ & $\begin{array}{l}\text { Maximum specific growth rate constant of } \\
\text { amendment and coal consuming bacteria } \\
\text { on amendment producing acetate }\end{array}$ \\
\hline
\end{tabular}

Continued on next page 
Table B.5 - continued from previous page

\begin{tabular}{|c|c|c|c|}
\hline Parameter & Value & Source & Brief Description \\
\hline$\mu_{\mathrm{ab}, \mathrm{Am}}^{\mathrm{H}_{2}}$ & $0.771 \mathrm{~d}^{-1}$ & $\begin{array}{l}\text { Estimated range: } \\
0.1-1.5 \mathrm{~d}^{-1}\end{array}$ & $\begin{array}{l}\text { Maximum specific growth rate constant of } \\
\text { amendment and coal consuming bacteria } \\
\text { on amendment producing hydrogen }\end{array}$ \\
\hline$\mu_{\mathrm{ab}, \mathrm{Am}}^{\mathrm{CH}_{3}}$ & $1.06 \mathrm{~d}^{-1}$ & $\begin{array}{l}\text { Estimated range: } \\
0.1-1.5 \mathrm{~d}^{-1}\end{array}$ & $\begin{array}{l}\text { Maximum specific growth rate constant of } \\
\text { amendment and coal consuming bacteria } \\
\text { on amendment producing methyl }\end{array}$ \\
\hline$\mu_{\text {ha }}$ & $0.253 \mathrm{~d}^{-1}$ & $\begin{array}{l}\text { Range [38]: } 0.05 \\
-4.07 \mathrm{~d}^{-1}\end{array}$ & $\begin{array}{l}\text { Maximum specific growth rate constant } \\
\text { of hydrogenotrophic archaea }\end{array}$ \\
\hline$\mu_{\text {aa }}$ & $0.279 \mathrm{~d}^{-1}$ & $\begin{array}{l}\text { Range } 39,38 \text { : } \\
0.08-2.49 \mathrm{~d}^{-1}\end{array}$ & $\begin{array}{l}\text { Maximum specific growth rate constant } \\
\text { of acetoclastic archaea }\end{array}$ \\
\hline$\mu_{\mathrm{ma}}$ & $1.06 \mathrm{~d}^{-1}$ & $\begin{array}{l}\text { Range [40]: } 0.2- \\
6 \mathrm{~d}^{-1}\end{array}$ & $\begin{array}{l}\text { Maximum specific growth rate constant } \\
\text { of methylotrophic archaea }\end{array}$ \\
\hline
\end{tabular}


Table B.6: Monod half saturations: The monod half saturations for every component that is involved in a reaction.

\begin{tabular}{|c|c|c|c|}
\hline \multicolumn{2}{|c|}{ Parameter Value } & Source & Brief Description \\
\hline$K_{\mathrm{Cc}}$ & $0.52 \mathrm{~g} / \mathrm{L}$ & $\begin{array}{l}\text { Estimated range: } \\
0.1-2 \mathrm{~g} / \mathrm{L}\end{array}$ & Monod half saturation constant for coal \\
\hline$K_{\mathrm{Am}}$ & $1.17 \mathrm{~g} / \mathrm{L}$ & $\begin{array}{l}\text { Estimated range: } \\
0.1-5 \mathrm{~g} / \mathrm{L}\end{array}$ & $\begin{array}{l}\text { Monod half saturation constant for } \\
\text { amendment }\end{array}$ \\
\hline$K_{\mathrm{H}_{2}}$ & $\begin{array}{l}7.65 \\
10^{-5} \mathrm{~g} / \mathrm{L}\end{array}$ & $\begin{array}{l}\text { Fitted, } 41] \text { esti- } \\
\text { mates: } 10^{-5} \mathrm{~g} / \mathrm{L}\end{array}$ & $\begin{array}{l}\text { Monod half saturation constant for hy- } \\
\text { drogen }\end{array}$ \\
\hline$K_{\mathrm{Ac}}$ & $\begin{array}{l}1.37 \\
10^{-3} \mathrm{~g} / \mathrm{L}\end{array}$ & $\begin{array}{l}\text { Fitted, estimated } \\
\text { range: } 1 \cdot 10^{-3}- \\
0.24 \mathrm{~g} / \mathrm{L} 42\end{array}$ & $\begin{array}{l}\text { Monod half saturation constant for ac- } \\
\text { etate }\end{array}$ \\
\hline$K_{\mathrm{CH}_{3}}$ & $\begin{array}{l}2.0 \\
10^{-3} \mathrm{~g} / \mathrm{L}\end{array}$ & $\begin{array}{l}\text { Fixed, according } \\
\text { to } 43\end{array}$ & $\begin{array}{l}\text { Monod half saturation constant for } \\
\text { methyl }\end{array}$ \\
\hline$k_{\mathrm{X}}$ & $1 \cdot 10^{-4} \mathrm{~d}^{-1}$ & $\begin{array}{l}\text { Fixed, estimated } \\
\text { to approx. min } \\
\text { growth rate / } 100\end{array}$ & Decay coefficient of all microorganisms \\
\hline
\end{tabular}

The respective yields for all the reactions for biomass or components are listed in Table B.7 and B.8. 
Table B.7: Biomass yields: The yields $Y_{X, S}^{P}$ are named after the microbe that is growing $X$, the substrate $S$ and, where applicable, the product they are producing $P$.

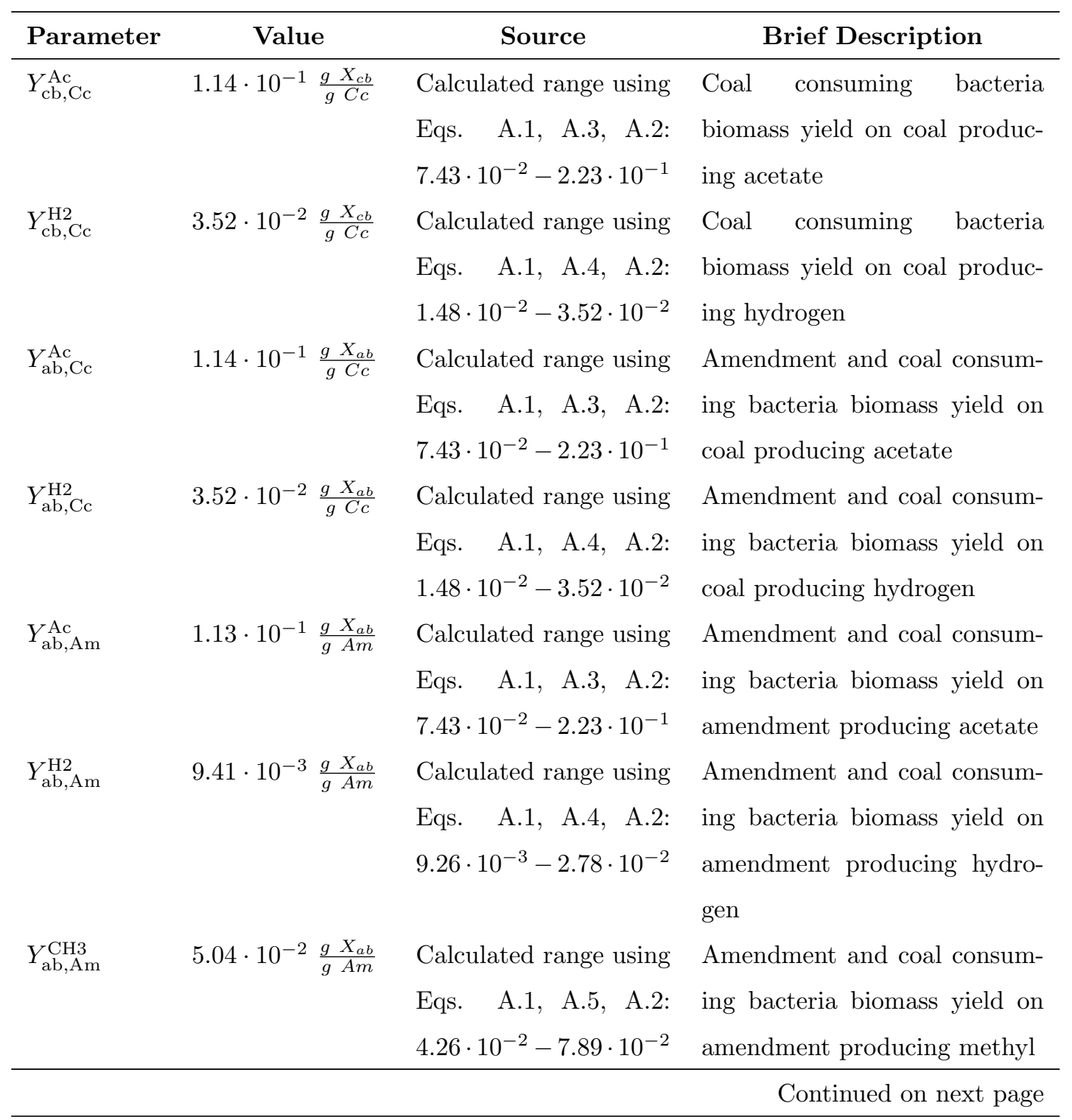


Table B.7 - continued from previous page

\begin{tabular}{|c|c|c|c|}
\hline Parameter & Value & Source & Brief Description \\
\hline$Y_{\mathrm{aa}, \mathrm{Ac}}$ & $3.10 \cdot 10^{-2} \frac{g X_{a a}}{g A c}$ & $\begin{array}{l}\text { Calculated range using } \\
\text { Eqs. A.6, A.8 A.7 } \\
2.86 \cdot 10^{-2}-5.36 \cdot 10^{-2}\end{array}$ & $\begin{array}{l}\text { Acetoclastic archaea biomass } \\
\text { yield on acetate }\end{array}$ \\
\hline$Y_{\mathrm{ha}, \mathrm{H}_{2}}$ & $1.22 \cdot 10^{-1} \frac{g X_{h a}}{g H_{2}}$ & $\begin{array}{l}\text { Calculated range using } \\
\text { Eqs. A.6, A.9 A.7. } \\
1.22 \cdot 10^{-1}-1.83\end{array}$ & $\begin{array}{l}\text { Hydrogenotrophic archaea } \\
\text { biomass yield on hydrogen }\end{array}$ \\
\hline$Y_{\mathrm{ma}, \mathrm{CH}_{3}}$ & $1.74 \cdot 10^{-1} \frac{g X_{m a}}{g C H_{3}}$ & $\begin{array}{l}\text { Calculated range using } \\
\text { Eqs. A.6, A.10, A.7 } \\
1.5 \cdot 10^{-1}-2.81 \cdot 10^{-1}\end{array}$ & $\begin{array}{l}\text { Methylotrophic archaea } \\
\text { biomass yield on methyl }\end{array}$ \\
\hline
\end{tabular}


Table B.8: Component yields: The yields are named $Y_{P, S}$ after their substrate $S$ and products $P$, where $S$ and $P$ are substituted for the respective components.

\begin{tabular}{|c|c|c|c|}
\hline Parameter & Value & Source & Brief Description \\
\hline$Y_{\mathrm{Ac}, \mathrm{Cc}}$ & $9.73 \cdot 10^{-1} \frac{g A c}{g C c}$ & $\begin{array}{l}\text { Calculated range using } \\
\text { Eqs. A.1, A.3 A.2. } \\
6.31 \cdot 10^{-2}-1.18\end{array}$ & Yield of acetate from coal \\
\hline$Y_{\mathrm{H}_{2}, \mathrm{Cc}}$ & $1.3 \cdot 10^{-2} \frac{g H_{2}}{g C c}$ & $\begin{array}{l}\text { Calculated range using } \\
\text { Eqs. A.1, A.4 A.2. } \\
1.30 \cdot 10^{-2}-1.95 \cdot 10^{-1}\end{array}$ & Yield of hydrogen from coal \\
\hline$Y_{\mathrm{Ac}, \mathrm{Am}}$ & $9.79 \cdot 10^{-1} \frac{g A c}{g A m}$ & $\begin{array}{l}\text { Calculated range using } \\
\text { Eqs. A.1. A.3 A.2. } \\
6.31 \cdot 10^{-1}-1.18\end{array}$ & $\begin{array}{l}\text { Yield of acetate from amend- } \\
\text { ment }\end{array}$ \\
\hline$Y_{\mathrm{H}_{2}, \mathrm{Am}}$ & $1.94 \cdot 10^{-01} \frac{g H_{2}}{g A m}$ & $\begin{array}{l}\text { Calculated range using } \\
\text { Eqs. A.1. A.4. A.2 } \\
1.04 \cdot 10^{-1}-1.95 \cdot 10^{-1}\end{array}$ & $\begin{array}{l}\text { Yield of hydrogen from amend- } \\
\text { ment }\end{array}$ \\
\hline$Y_{\mathrm{CH}_{3}, \mathrm{Am}}$ & $6.96 \cdot 10^{-1} \frac{g C H_{3}}{g A m}$ & $\begin{array}{l}\text { Calculated range using } \\
\text { Eqs. A.1, A.5, A.2 } \\
5.29 \cdot 10^{-1}-9.91 \cdot 10^{-1}\end{array}$ & $\begin{array}{l}\text { Yield of methyl from amend- } \\
\text { ment }\end{array}$ \\
\hline$Y_{\mathrm{CH}_{4}, \mathrm{Ac}}$ & $2.93 \cdot 10^{-1} \frac{g C H_{4}}{g A c}$ & $\begin{array}{l}\text { Calculated range using } \\
\text { Eqs. A.6, A.8 A.7 } \\
2.07 \cdot 10^{-1}-3.88 \cdot 10^{-1}\end{array}$ & Yield of $\mathrm{CH}_{4}$ from acetate \\
\hline$Y_{\mathrm{CH}_{4}, \mathrm{H}_{2}}$ & $2.89 \frac{g C H_{4}}{g H_{2}}$ & $\begin{array}{l}\text { Calculated range using } \\
\text { Eqs. A.6, A.9. A.7 } \\
1.26 \cdot 10^{-1}-2.98\end{array}$ & Yield of $\mathrm{CH}_{4}$ from hydrogen \\
\hline$Y_{\mathrm{CH}_{4}, \mathrm{CH}_{3}}$ & $3.3 \cdot 10^{-1} \frac{g C H_{4}}{g C H_{3}}$ & $\begin{array}{l}\text { Calculated range using } \\
\text { Eqs. A.6, A.10, A.7. } \\
2.47 \cdot 10^{-2}-4.63 \cdot 10^{-1}\end{array}$ & Yield of $\mathrm{CH}_{4}$ from methyl \\
\hline
\end{tabular}


Table B.8 - continued from previous page

\begin{tabular}{lccc}
\hline Parameter & Value & Source & Brief Description \\
\hline$Y_{\mathrm{CO}_{2}, \mathrm{Ac}}$ & $8.05 \cdot 10^{-1} \frac{g C O_{2}}{g A c}$ & Calculated range using & Yield of $\mathrm{CO}_{2}$ from acetate \\
& & Eqs. A.6, A.8, A.7. & \\
& & $5.69 \cdot 10^{-1}-1.07$ & \\
$Y_{\mathrm{CO}_{2}, \mathrm{H}_{2}}$ & $4.46 \cdot 10^{-1} \frac{g C O_{2}}{g H_{2}}$ & Calculated range using & Yield of $\mathrm{CO}_{2}$ from hydrogen \\
& & Eqs. A.6, A.9, A.7. & \\
& & $1.88 \cdot 10^{-1}-4.46 \cdot 10^{-1}$ & \\
$Y_{\mathrm{CO}_{2}, \mathrm{CH}_{3}}$ & $1.73 \cdot 10^{-1} \frac{g C \mathrm{O}_{2}}{g C H_{3}}$ & Calculated range using & Yield of $\mathrm{CO}_{2}$ from methyl \\
& & Eqs. A.6, A.10, A.7. & \\
& & $1.29 \cdot 10^{-1}-2.43 \cdot 10^{-1}$ & \\
\hline \hline
\end{tabular}


Appendix C. MECBM summary of equations 


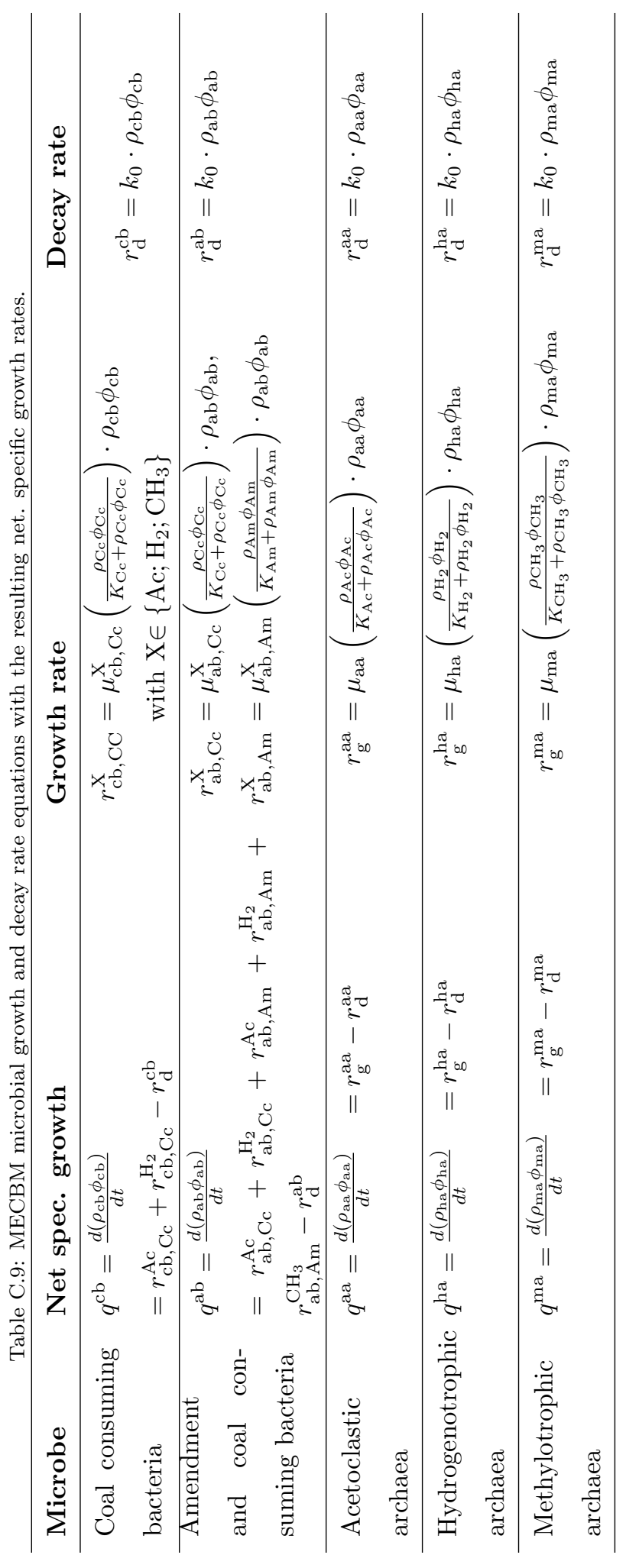


Table C.10: Relevant MECBM component reaction equations.

\begin{tabular}{|c|c|}
\hline Component & Source and sink term \\
\hline Acetate & $q^{\mathrm{Ac}}=r_{\mathrm{cb}, \mathrm{Cc}}^{\mathrm{Ac}} \cdot \frac{Y_{\mathrm{Ac}, \mathrm{Cc}}^{\mathrm{Ac}}}{Y_{\mathrm{cb}, \mathrm{Cc}}^{\mathrm{A}}}+r_{\mathrm{ab}, \mathrm{Cc}}^{\mathrm{Ac}} \cdot \frac{Y_{\mathrm{Ac}, \mathrm{Cc}}^{\mathrm{Ac}}}{Y_{\mathrm{ab}, \mathrm{Cc}}^{\mathrm{Ac}}}+r_{\mathrm{ab}, \mathrm{Am}}^{\mathrm{Ac}} \cdot \frac{Y_{\mathrm{Ac}, \mathrm{Am}}}{Y_{\mathrm{ab}, \mathrm{Am}}^{\mathrm{Ac}}}-\frac{r_{\mathrm{aa}}}{Y_{\mathrm{aa}, \mathrm{Ac}}}$ \\
\hline Amendment & $q^{\mathrm{Am}}=-\left(\frac{r_{\mathrm{ab}, \mathrm{Am}}^{\mathrm{Ac}}}{Y_{\mathrm{ab}, \mathrm{Am}}^{\mathrm{Ac}}}+\frac{r_{\mathrm{ab}, \mathrm{Am}}^{\mathrm{H}_{2}}}{Y_{\mathrm{ab}, \mathrm{Am}}^{\mathrm{H}}}+\frac{r_{\mathrm{ab}, \mathrm{Am}}^{\mathrm{CH}_{3}}}{Y_{\mathrm{ab}, \mathrm{Am}}^{\mathrm{CH}}}\right)$ \\
\hline $\mathrm{CH}_{4}$ & $q^{\mathrm{CH}_{4}}=r_{\mathrm{aa}} \cdot \frac{Y_{\mathrm{CH}_{4}, \mathrm{Ac}}}{Y_{\mathrm{aa}, \mathrm{Ac}}}+r_{\mathrm{ha}} \cdot \frac{Y_{\mathrm{CH}_{4}, \mathrm{H}_{2}}}{Y_{\mathrm{ha}, \mathrm{H}_{2}}}+r_{\mathrm{ma}} \cdot \frac{Y_{\mathrm{CH}_{4}, \mathrm{CH}_{3}}}{Y_{\mathrm{ma}, \mathrm{CH}_{3}}}$ \\
\hline $\mathrm{CO}_{2}$ & $q^{\mathrm{CO}_{2}}=r_{\mathrm{aa}} \cdot \frac{Y_{\mathrm{CO}_{2}, \mathrm{Ac}}}{Y_{\mathrm{aa}, \mathrm{Ac}}}+r_{\mathrm{ma}} \cdot \frac{Y_{\mathrm{CO}_{2}, \mathrm{CH}_{3}}}{Y_{\mathrm{ma}, \mathrm{CH}_{3}}}-\frac{r_{\mathrm{ha}}}{Y_{\mathrm{ha}, \mathrm{CO}_{2}}}$ \\
\hline Coal & $q^{\mathrm{Cc}}=-\left(\frac{r_{\mathrm{cb}, \mathrm{Cc}}^{\mathrm{Ac}}}{Y_{\mathrm{cb}, \mathrm{Cc}}^{\mathrm{Ac}}}+\frac{r_{\mathrm{cb}, \mathrm{Cc}}^{\mathrm{H}_{2}}}{Y_{\mathrm{cb}, \mathrm{Cc}}^{\mathrm{H}}}+\frac{r_{\mathrm{ab}, \mathrm{Cc}}^{\mathrm{Ac}}}{Y_{\mathrm{ab}, \mathrm{Cc}}^{\mathrm{Ac}}}+\frac{r_{\mathrm{ab}, \mathrm{Cc}}^{\mathrm{H}_{2}}}{Y_{\mathrm{ab}, \mathrm{Cc}}^{\mathrm{H}}}+\frac{r_{\mathrm{ab}}^{\mathrm{CH}, \mathrm{Cc}}}{Y_{\mathrm{ab}, \mathrm{Cc}}^{\mathrm{CH}}}\right)$ \\
\hline Hydrogen & $q^{\mathrm{H}_{2}}=r_{\mathrm{cb}, \mathrm{Cc}}^{\mathrm{H}_{2}} \cdot \frac{Y_{\mathrm{H}_{2}, \mathrm{Cc}}}{Y_{\mathrm{cb}, \mathrm{Cc}}^{\mathrm{H}}}+r_{\mathrm{ab}, \mathrm{Cc}}^{\mathrm{H}_{2}} \cdot \frac{Y_{\mathrm{H}_{2}, \mathrm{Cc}}}{Y_{\mathrm{ab}, \mathrm{Cc}}^{\mathrm{H}}}+r_{\mathrm{ab}, \mathrm{Am}}^{\mathrm{H}_{2}} \cdot \frac{Y_{\mathrm{H}_{2}, \mathrm{Am}}}{Y_{\mathrm{ab}, \mathrm{Am}}^{\mathrm{H}}}-\frac{r_{\mathrm{ha}}}{Y_{\mathrm{ha}, \mathrm{H}_{2}}}$ \\
\hline Methyl & $q^{\mathrm{CH}_{3}}=r_{\mathrm{ab}, \mathrm{Am}}^{\mathrm{CH}_{3}} \cdot \frac{Y_{\mathrm{CH}_{3}, \mathrm{Am}}}{Y_{\mathrm{ab}, \mathrm{Am}}^{\mathrm{CH}}}-\frac{r_{\mathrm{ma}}}{Y_{\mathrm{ma}, \mathrm{CH}}}$ \\
\hline
\end{tabular}




\section{Acknowledgments}

Funded by the Deutsche Forschungsgemeinschaft (DFG, German Research

${ }_{680}$ Foundation) Project Number CL190-3 and we thank the DFG for supporting this work by funding SFB 1313, Project Number 327154368. The authors would like to thank Irfan Mahmood and his work during his Master's thesis, as well as Johannes Hommel, which contributed to laying the foundation of a simplified MECBM-model.

685 